\title{
Effects of Volatile Fatty Acid Proportions on Energy and Nitrogen Utilization in Early Weaned Calves Nourished by Intragastric Infusion of Nutrients
}

\author{
Taketo Obitsu, Kohzo Taniguchi and Yoji Yamatani \\ Faculty of Applied Biological Science, Hiroshima \\ University, Higashihiroshima-shi 724
}

(Received October 7, 1992)

\begin{abstract}
Six male Holstein calves aged 6 to $14 \mathrm{wk}$ were intraruminally given volatile fatty acids (VFA) containing acetic, propionic and butyric acids in the molar proportions $48: 42: 10$ and $76: 14: 10$ with abomasal infusion of casein. Calves were weaned at 5 to $7 \mathrm{wk}$ of age and were then wholly nourished by intragastric infusion of nutrients. Gross energy and nitrogen $(\mathrm{N})$ infused was $570 \mathrm{~kJ} / \mathrm{kg} \mathrm{BW}$ and $1.0 \mathrm{~g} / \mathrm{kg} \mathrm{BW} \mathrm{BW}^{0.75}$, respectively. Heat production, $\mathrm{N}$ balance and concentrations of plasma metabolites were determined every $2 \mathrm{wk}$ from age 6 to $14 \mathrm{wk}$. Plasma concentrations of glucose and $\beta$-hydroxybutyrate were affected by the proportion of VFA. Heat production per unit metabolic body weight was not affected by the proportion of VFA, but tended to decrease with advancing age. At age 10 and $12 \mathrm{wk}, \mathrm{N}$ retention for calves with the low propionate was lower than with the high propionate. These results indicate that, for a few weeks after weaning, the decrease in the ruminal propionate proportion probably reduces the $\mathrm{N}$ use for body protein synthesis in young calves, even though the decrease in the propionate proportion is within the normal range found in ruminants.
\end{abstract}

Anim. Sci. Technol. (Jpn.) 64 (6):568-577, 1993

Key words: volatile fatty acids, heat production, nitrogen retention, calves, early weaning

Early weaning of calves contributes to early development of the rumen because of accelerated intake of dry feed ${ }^{20)}$. After weaning, calves depend largely on volatile fatty acids (VFA) instead of glucose to satisfy their energy needs for growth. For the few weeks after weaning, however, rumen function ${ }^{2(1)}$ and the ability to utilize VFA in tissues ${ }^{25)}$ do not reach a mature level. Thus, the efficiency of utilization of VFA for energy retention in earlyweaned calves may differ from that in mature ruminants.

In mature ruminants, the decrease in the ruminal propionate proportions within the physiological range did not affect nitrogen (N) retention in the whole body ${ }^{18,19)}$, although

Anim. Sei. Technol. (Jpn.) 64 (6) : 568-577 hepatic removal of amino acids for glucose production increases with decreased propionate release by portal-drained viscera ${ }^{237}$. Young ruminants, however, require large quantities of amino acids as well as glucose in comparison with mature ${ }^{30)}$. Thus, early-weaned calves may decrease the efficiency of $\mathrm{N}$ use for body protein synthesis with low ruminal proportions of propionate, even though the reduction in the propionate proportion is within the normal range.

Recently, an intragastric infusion technique was developed ${ }^{17)}$, in which ruminant animals are wholly nourished by purified nutrients infused into the rumen and abomasum. Because the supply of nutrients is controlled 
Calf no.

$1(\mathrm{P}), 2$ (A)

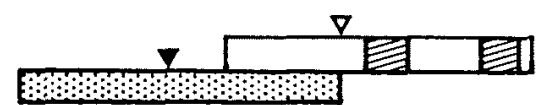

$3(\mathrm{P}), 5(\mathrm{~A})$

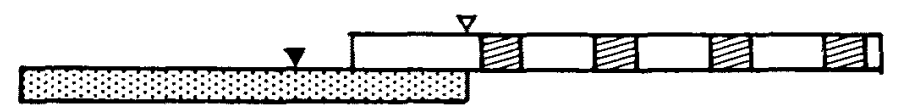

$4(\mathrm{P}), 6(\mathrm{~A})$
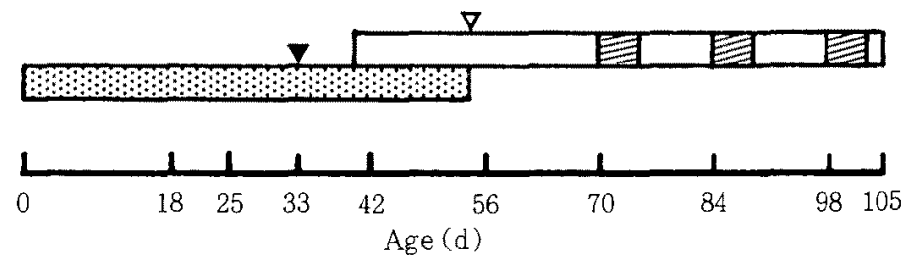

Fig. 1. Experimental scheme during milk-fed period (:3) and infusion period ( $\square$ ) for individual calves infused with VFA mixtures containing acetic, propionic and butyric acids in the molar proportions $48: 42: 10(\mathrm{P})$ and $76: 14: 10(\mathrm{~A})$.

: measuremental period, $\nabla:$ cannulation, $\nabla:$ weaning.

quantitatively, this technique allows direct estimation of the contribution of VFA to nutrient utilization in the host animal without the complications of ruminal fermentation. However, few studies were reported, in which the intragastric infusion technique was used for young calves less than $100 \mathrm{~kg}$ body weight.

The purpose of this study was to determine the effects of different proportions of VFA infused into the rumen on utilization of energy and $\mathrm{N}$ and plasma metabolites in the earlyweaned calves sustained by intragastric infusion of nutrients.

\section{Materials and Methods}

Animals, management and treatments: Six male Holstein calves (average birth weight 43 $\pm 7.7 \mathrm{~kg}$ ) were used. The animals and the experimental scheme are shown in Fig. 1. At 3 $\mathrm{d}$ of age, the calves were housed in metabolism crates in a room at $20^{\circ} \mathrm{C}$. The calves were fed colostrum until $3 \mathrm{~d}$ of age. Subsequently, two calves (calves 1 and 2) were fed whole milk at $10 \%$ of body weight daily until $39 \mathrm{~d}$ old, and the remainder (calves 3, 4, 5 and 6) were given the same amount until $54 \mathrm{~d}$ old. At $18 \mathrm{~d}$ (calves 1 and 2) and $33 \mathrm{~d}$ (calves 3, 4, 5 and 6), the calves were fitted with a ruminal cannula ( $26 \mathrm{~mm}$ OD $\times 70 \mathrm{~mm} \times 2 \mathrm{~mm}$ wall thickness) and an abomasal catheter $(5 \mathrm{~mm} \mathrm{OD} \times 40 \mathrm{~cm} \times$ $0.5 \mathrm{~mm}$ wall thickness) as described elsewhere ${ }^{16)}$. At $7 \mathrm{~d}$ after surgical preparation, the calves were assigned to two treatments ( $P$ and $\mathrm{A}$ ), and nutrient infusion commenced. The calves in treatment $P$ (calves 1,3 and 4 ) and in treatment $A$ (calves 2, 5 and 6) were infused with VFA mixtures containing acetic, propionic and butyric acids in the following molar proportions, respectively: 48, 42 and $10 ; 76,14$ and 10. These high and low propionic acid mixtures were planned as the maximum and minimum level within the range of the propionic acid proportions normally found in mature ruminants ${ }^{18)}$.

During the first $14 \mathrm{~d}$ of infusion, the amount of both VFA and casein infused gradually increased to reach a level 1.3 times maintenance requirement. In our preliminary experiment ${ }^{16)}$, this level of infusion was at a maximum to successfully maintain the $\mathrm{pH}$ and osmotic pres- 
sure in the rumen of early-weaned calves. After weaning, they were wholly nourished by purified nutrients infused into the rumen and abomasum; the total daily energy and casein infused were $570 \mathrm{~kJ} / \mathrm{kgBW}^{0.75}$ and $1.0 \mathrm{~g} \mathrm{~N} / \mathrm{kg}$ $\mathrm{BW}^{0.75}$, respectively. These levels (1.3 times maintenance) are equal to the requirements of metabolizable energy ${ }^{27}$ and absorbed $\mathrm{N}^{1,2}$ which support approximately $0.3 \mathrm{~kg} / \mathrm{d}$ of liveweight gain. The planned amounts of VFA infused were based on the heat combustion of acetic $(875 \mathrm{~kJ} / \mathrm{mol})$, propionic $(1527 \mathrm{~kJ} / \mathrm{mol})$ and butyric acid $(2184 \mathrm{~kJ} / \mathrm{mol})^{6}$. The planned amount of casein infused was based on the gross energy $(21.9 \mathrm{~kJ} / \mathrm{g})$ and the total $\mathrm{N}$ content $(135 \mathrm{~g} / \mathrm{kg})$ determined by bomb calorimeter (model CA-3, Shimazu) and by a Kjeldahl method, respectively. The average amounts of VFA and casein actually infused are shown in Table 1. Major and trace minerals and vitamins were also infused according to the energy level as described by $\varnothing$ Rskov et al. ${ }^{17)}$. Polypropylene ropes, as substitute roughage, were placed in the rumen to stimulate ruminal development and to maintain ruminal motility.

Infusion procedures: The details of the modified technique for the infusion procedures for sheep ${ }^{17}$ were clescribed in our other report ${ }^{(f)}$. In brief; the solution of the VFA

Table 1. Daily amounts of VFA and casein infused into calves

\begin{tabular}{|c|c|c|c|c|}
\hline \multirow{2}{*}{ Infusate } & \multicolumn{4}{|c|}{ Treatment } \\
\hline & & $\mathrm{P}$ & & A \\
\hline \multicolumn{5}{|l|}{ VFA, mmol $/ \mathrm{kg} \mathrm{BW}^{0.75}$} \\
\hline Acetic acid & 155 & \pm 13.8 & 286 & \pm 19.3 \\
\hline Propionic acid & 136 & \pm 10.7 & 50 & \pm 3.3 \\
\hline Butyric acid & 35 & \pm 2.8 & 38 & \pm 2.6 \\
\hline Casein, g/kg BW 0.75 & \multicolumn{2}{|c|}{$7.4 \pm 0.3$} & \multicolumn{2}{|c|}{$7.4 \pm 0.6$} \\
\hline $\begin{array}{l}\text { Gross energy, } \mathrm{kJ} / \mathrm{kg} \\
\mathrm{BW} W^{0.15}\end{array}$ & 581 & \pm 36.5 & 571 & \pm 29.6 \\
\hline Nitrogen, $\mathrm{g} / \mathrm{kg}$ BW 0.75 & \multicolumn{2}{|c|}{$1.0 \pm 0.04$} & \multicolumn{2}{|c|}{$1.0 \pm 0.03$} \\
\hline
\end{tabular}

mixture $(10 \mathrm{l} / \mathrm{d})$ containing major minerals and the buffer solution (10 to $15 l / d$ ) were infused into the rumen separately, and a casein-vitamin mixture $(3 l / \mathrm{d})$ and trace minerals $(50 \mathrm{ml}$ d) were infused into the abomasum. These infusates were prepared daily according the body weight measured every $2 \mathrm{wk}$. The daily amount of buffer infused was approximately $0.4 \mathrm{~mol}$ bicarbonate/mol VFA. The actual amount and concentration of the buffer solution were adjusted daily according to ruminal $\mathrm{pH}$ and osmotic pressure to keep ruminal $\mathrm{pH}$ above 5.5 and ruminal osmotic pressure below 350 $\mathrm{mOsm} / l$.

Measurements: Measurement of plasma metabolites, $\mathrm{N}$ balance and heat production was conducted at 6 and $8 \mathrm{wk}$ of age for calves 1 and 2 , at $8,10,12$ and $14 \mathrm{wk}$ for calves 3 and 5 , and at 10,12 and $14 \mathrm{wk}$ for calves 4 and 6 (Fig. 1). These differences in measurement age were due to variation of weaning age, incidence of diarrhoea and use for other measurements. During each measuremental period, urine and feces were collected daily for $5 \mathrm{~d}$. Daily urine samples were pooled in each period and stored at $-20^{\circ} \mathrm{C}$. Daily samples of feces were dried at $60^{\circ} \mathrm{C}$ in an air-forced oven, and then the dried samples were pooled in each period. On both the first and last day during each collection period, blood samples were taken from the jugular vein at 15:00. Plasma was immediately separated and stored at $-20^{\circ} \mathrm{C}$.

During the collection period, heat production over $24 \mathrm{~h}$ was measured by indirect calorimetry with a ventilated hood ${ }^{14)}$. A head cage $(60 \times$ $80 \times 90 \mathrm{~cm}$ ) with both an inlet and an outlet duct was set on the metabolism crate $12 \mathrm{~h}$ prior to the respiratory trial. Air was drawn through the hood at the rate of $100 \mathrm{l} / \mathrm{min}$ by negative pressure created by a pump (model VFC084P, Fuji Electric) downstream. The actual flow rate was measured by mass flow meter (model 2010, Kojima) setting prior to the pump. Oxygen concentration of the gas sample obtained from the outlet of the flow 
meter was continuously analyzed by a mass spectrometer (model WSMR-1400B, Westron). The flow rate and oxygen concentration of the outlet gas were recorded every $12 \mathrm{~s}$ by a recorder (model DL1200, NEC Sanei). Outside air was sampled for $15 \mathrm{~min}$ every $4 \mathrm{~h}$. Calibration of this system was conducted after each respiration trial by the $\mathrm{N}$ recovery test ${ }^{14)}$. Hourly heat production was calculated by MCLEAN's equation ${ }^{14)}$.

Nitrogen in feces and urine was analyzed by a Kjeldahl method. Concentrations of plasma glucose $^{12)}$ and $\beta$-hydroxybutyrate ${ }^{33)}$ ( $\beta \mathrm{HOB}$ ) were determined by enzymatic methods. Plasma urea- $\mathrm{N}$ concentration was analyzed by calorimetry without deproteinization ${ }^{\text {?). Plasma }}$ concentration of free amino acids was determined by HPLC (JASCO) with post-column owphthalaldehyde detection ${ }^{9}$.
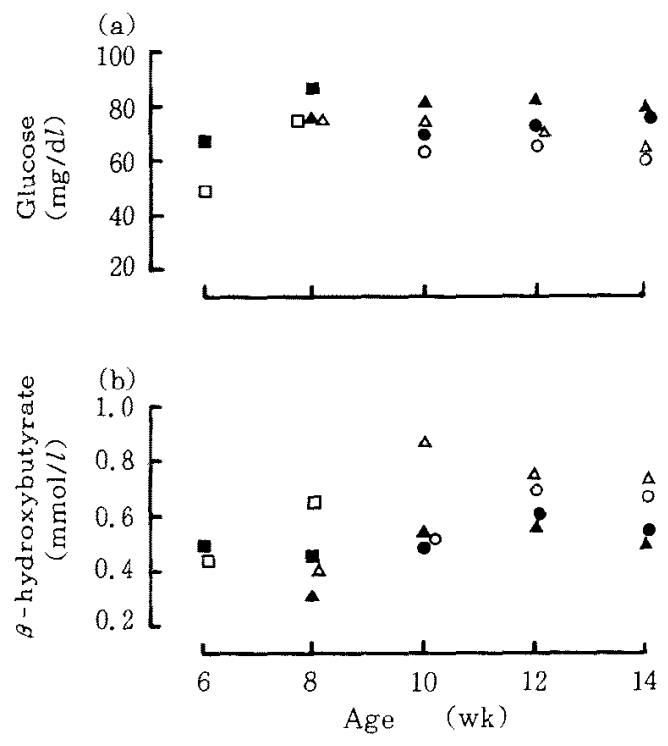

Fig. 2. Plasma concentration of glucose (a) and $\beta$-hydroxybutyrate (b) from 6 to $14 \mathrm{wk}$ of age for individual calves infused with VFA mixtures containing acetic, propionic and butyric acids in the molar proportions $48: 42$ : 10 ( $\mathbf{0}$ : calf $1, \boldsymbol{\Delta}$ : calf $3, \boldsymbol{O}:$ calf 4 ) and 76 : $14: 10(\square:$ calf $2, \Delta:$ calf $5, O$ : calf 6$)$.

\section{Results}

Animal health: Daily body-weight gain for calves 1 and 2 from 6 to $8 \mathrm{wk}$ was 0.16 and 0.28 $\mathrm{kg}$, respectively. The other four calves gained weight at the rate of 0.24 to $0.50 \mathrm{~kg} / \mathrm{d}$ from age 8 to $14 \mathrm{wk}$. Thses valucs wore nearly equal to expected body-weight gain, and were not affected by the proportion of VFA. During the infusion period, no leakage of ruminal fluid through the fistula was observed. However, calves in each treatment sometimes had diarrhoea associated with ruminal acidity and high ruminal osmotic pressure until $10 \mathrm{wk}$ of age. After $12 \mathrm{wk}$, diarrhoea was not observed.

Concentration of plasma metabolites: Plasma glucose concentration (Fig. 2a) for calves 1 and 2 increased from 6 to 8 wh of age. After $8 \mathrm{wk}$, plasma glucose levels for calves in each treatment (calves 3 and 4 in treatment $P$ and calves 5 and 6 in treatment A) were relatively constant, and the levels tended to be higher for calves in treatment $\mathrm{P}$ than for those in treatment A. Plasma concentration of $\beta \mathrm{HOB}$ (Fig. 2b) for calf 1 in treatment $P$ did not changed from 6 to $8 \mathrm{wk}$ of age, whereas that for calf 2 in treatment $A$ increased from 6 to 8 wk. Plasma concentration of $\beta \mathrm{HOB}$ for calve in each treatment increased slightly from age 8 to $12 \mathrm{wk}$, but then remained relatively constant. After 12 wh of age, $\beta \mathrm{HOB}$ was higher in calves in treatment $A$ (calves 5 and 6) than in those in treatment $\mathrm{P}$ (Calves 3 and 4). Plasma urea-N concentration (Fig. 3a) was not affected by VFA proportions or by age. Plasma concentrations of total, essential and nonessential amino acids (Fig. 3b, 3c, and 3d) for calf 1 was higher than those in calf 2. After 8 wk of age, neither VFA proportions nor age affected the plasma concentrations of amino acids.

Heat production and $N$ retention: Daily heat production of calves at various ages is shown in Fig. 4. The lack of data for calf 3 at 10 wh and calf 5 at 12 wk was due to troubles associated with the measurement system. Heat 

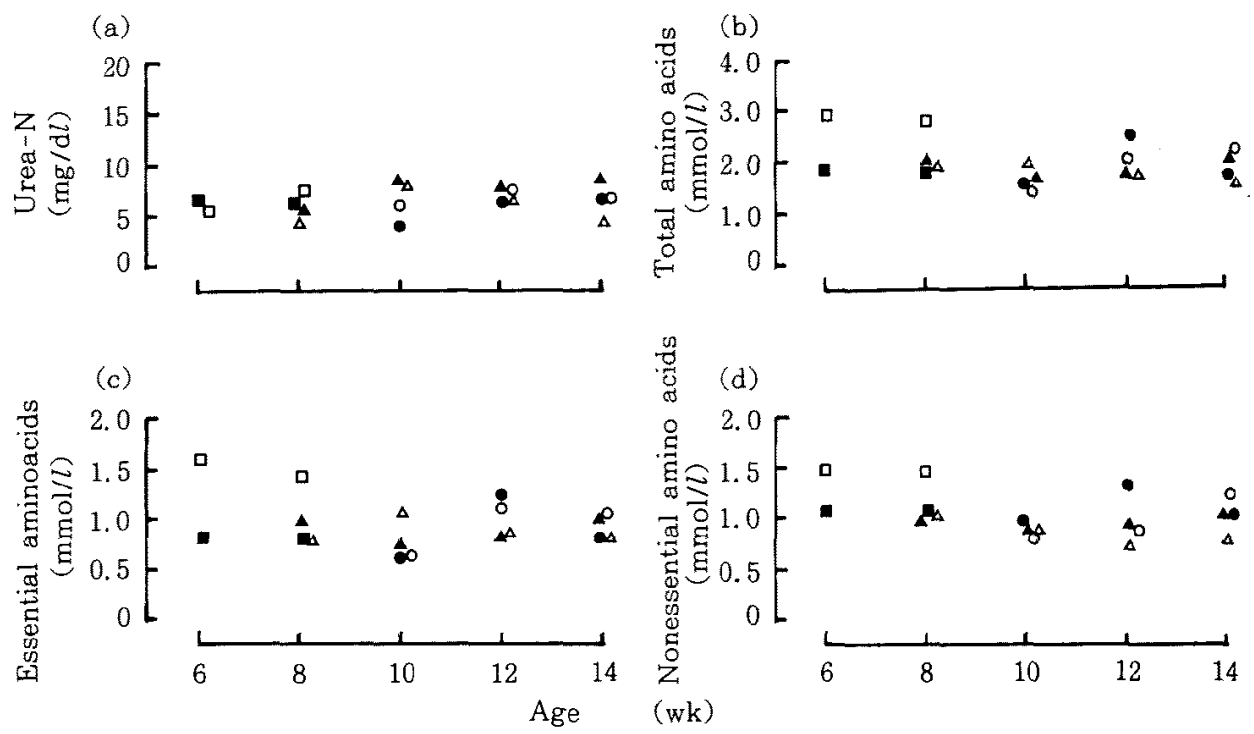

Fig. 3. Plasma concentration of urea-N (a), total amino acids (b), essential amino acids (c) and nonessential amino acids (d) from 6 to 14 wk of age for individual calves infused with VFA mixtures containing acetic, propionic and butyric acids in the molar proportions $48: 42: 10$ ( $\square$ : calf $1, \mathbf{\Delta}$ : calf $3, \bigcirc:$ calf 4$)$ and $76: 14: 10(\square:$ calf $2, \triangle:$ calf $5, \bigcirc:$ calf 6 ).

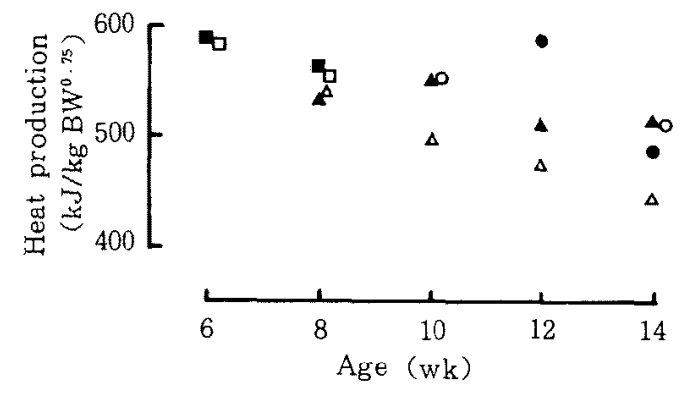

Fig. 4. Daily heat production from 6 to 14 wh of age for individual calves infused with VFA mixtures containing acetic, propionic and butyric acids in the molar proportions 48 : $42: 10(\mathbf{\square}$ : calf, $\boldsymbol{\Lambda}$ : calf $3, \bullet:$ calf 4$)$ and 76 : $14: 10(\square:$ calf $2, \triangle$ : calf $5, O$ : calf 6$)$.

production for calves 1 and 2 at 6 wh of age tended to be higher than that for calves at other ages. For calves in treatment $A$, there was a negative relationship $(r=-0.81, P<0.05)$ between heat production and age. For calves in treatment $P$, although there was no significant relationship $(r=-0.59, \quad P>0.10)$, heat production also tended to decrease with advancing age. However, heat production was not affected by VFA proportions at any age. Mean heat production and standard deviation of 8 observations for calves in each treatment was $545 \pm 37.5$ (treatment $P$ ) and $522 \pm 43.6 \mathrm{~kJ} / \mathrm{kg}$ $\mathrm{BW}^{0.25}$ (treatment A).

Fecal $\mathrm{N}$ excretion was negligible ( 8 to $44 \mathrm{mg}$ ) $\left.\mathrm{kg} \mathrm{BW}{ }^{0.75}\right)$; therefore, the change in $\mathrm{N}$ retention (Fig. 5) reflected urinary $N$ excretion. Nitrogen retention for calves in treatment $P$ slightly decreased with advancing age, so there was a negative relationship $(\mathrm{r}=-0.66, \mathrm{P}<0.10)$ between $\mathrm{N}$ retention and age. Nitrogen retention for calves 5 and 6 in treatment A rapidly decreased at 10 and $12 \mathrm{wk}$ respectively, but at $14 \mathrm{wk}$, it again reached the level of 8 or $10 \mathrm{wk}$. Mean $\mathrm{N}$ retention and standard deviation of 9 observations between 6 and $14 \mathrm{wk}$ of age for calves in each treatment was $435 \pm 44.6$ 


\section{VFA Utilization in Early Weaned Calves}

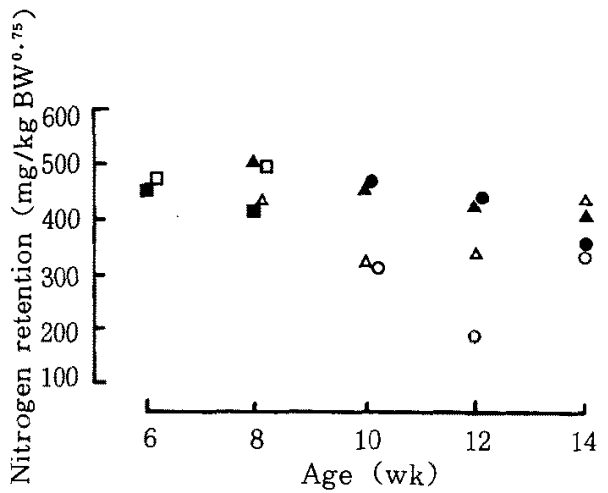

Fig. 5. Daily nitrogen retention from 6 to 14 wh of age for individual calves infused with VFA mixtures containing acetic, propionic and butyric acids in the molar proportions 48 : $42: 10$ ( $\mathbf{\square}$ : calf $1, \boldsymbol{\Delta}$ : calf $3, \mathbf{O}$ : calf 4 ) and 76 : $14: 10$ ( $\square$ : calf $2, \Delta$ : calf $5, \bigcirc$ : calf 6 ) .

(treatment P) and $373 \pm 105.6 \mathrm{mg} / \mathrm{kg} \quad \mathrm{BW}^{0.75}$ (treatment A).

\section{Discussion}

Plasma metabolites: Blood glucose concentration for newborn calves gradually decreases with advancing age, reaching the mature level within a few weeks after weaning due to physiological and dietary factors ${ }^{21)}$. In the present study, plasma glucose concentration increased from 6 to $8 \mathrm{wk}$ of age, and thereafter it maintained a constant level. Between 8 and $14 \mathrm{wk}$ age, plasma glucose concentration with the high propionate tended to be higher than with the low propionate infusion. This difference in glucose concentration probably reflects the supply of glucogenic precursors to the animals. However, ØRsKov et al. ${ }^{19)}$ reported that reduction in plasma glucose concentration did not occurred in steers nourished by intragastric infusion until the propionate proportion in the VFA mixture reduced below $6 \mathrm{~mol} / 100 \mathrm{~mol}$.

Plasma $\beta \mathrm{HOB}$ concentration increased from 6 to $10 \mathrm{wk}$ of age, similar to early-weaned calves fed conventional diets as reported by
QUigley et $a l^{21}{ }^{21}$. Metabolic activity converting butyrate to $\beta \mathrm{HOB}$ in ruminal tissue increases rapidly after weaning ${ }^{4}$. The similar change in metabolism of butyrate in the ruminal tissue probably occurred in our calves nourished by intragastric infusion. After 10 wk, plasma $\beta \mathrm{HOB}$ concentration for calves was higher when the VFA contained $14 \mathrm{~mol}$ propionic acid $/ 100 \mathrm{~mol}$ than when it contained $42 \mathrm{~mol} / 100 \mathrm{~mol}$. Because a shortage of oxalacetic acid derived from glucose or glucose precursors in the liver increases hepatic ketogenesis from acetyl-CoA ${ }^{24)}$, the elevation in blood $\beta H O B$ concentration implies a shortage of glucose precursors. However, Ørskov et $a l .{ }^{19)}$ found that plasma $\beta$ HOB concentration in steers nourished by intragastric infusion did not increase until propionate in the VFA mixture reduced below $11 \mathrm{~mol} / 100 \mathrm{~mol}$.

Plasma concentration of urea-N and free amino acids, which generally related to the nutritional condition of protein in animals, did not reflected $\mathrm{N}$ balance in the present study. However, EskEl.AND et al. ${ }^{10)}$ reported that low plasma concentration of essential amino acids associated with decreased urinary $N$ excretion was observed when propionate was infused intravenously into sheep. Because propionate absorbed from the rumen was extensively metabolized by the spalanchnic visceral tissues $^{3)}$, the amount of propionate present in the circulation is small. Therefore, the results obtained by intraruminal infusion of VFA may differ from the results by intravenous administration.

Utilization of VFA energy: The proportion of VFA infused into the rumen, in the present work, did not affect heat production in earlyweaned calves. Similar results for sheep and steers have been reported by $\varnothing \mathrm{RSKOV}$ et al. ${ }^{18,19)}$. In steers given 1.5 times maintenance energy ${ }^{19}$, alteration of the molar proportion of VFA (from 1 to $81 \mathrm{~mol}$ propionic acid/100 mol) did not affect heat production until the propionic acid proportion decreased to $1 \mathrm{~mol} / 100 \mathrm{~mol}$. In 
their experiment ${ }^{19)}$, the efficiency of utilization of VFA for energy retention was 0.55 , irrespective of VFA proportions.

SEKINE et al. ${ }^{28)}$ reported that efficiency of utilization of metabolizable energy for growth in early-wcaned calves at 7,9 and 13 wh was $0.48,0.52$ and 0.52 , respectively. In the present study, heat production by calves was the highest at $6 \mathrm{wk}$, but then it slightly decreased with advancing age. This change in heat production with advancing age may be associated with alteration in the energy cost of protein synthesis in the tissues. The rate of protein synthesis is high in young animals, and decreased with advancing maturity ${ }^{11}$. In fact, in the present study, $\mathrm{N}$ retention tended to decreased with advancing age. Generally, energy expenditure for body protein synthesis is higher than that for fat synthesis ${ }^{22}$. Therefore, efficiency of utilization of VFA energy for growth probably increased with decreases in the proportion of protein deposition in empty-body weight gain.

Wasteful utilization of acetate associated with a shortage of glucose or glucose precursors ${ }^{13,31)}$ may account for the high heat production in the calves 1 and 2 at $6 \mathrm{wk}$ in this study. Glucose produced from glucogenic precursors is probably affected not only by the availability of the precursors but also by the activity of gluconeogenic enzymes. The activity of these enzymes in milk-fed calves is low, but it increases twofold between 8 to $12 \mathrm{wk}^{5}$. Therefore, for the calves weaned early in the present study, the supply of glucose produced from glucogenic precursors may be insufficient for animal's need; plasma glucose concentration was relatively low in these calves at $6 \mathrm{wk}$ of age.

Nitrogen utilization: In the present study, when the proportion of propionic acid was $14 \mathrm{~mol} / 100 \mathrm{~mol}$, reduction in $\mathrm{N}$ retention occurred at 10 and $12 \mathrm{wk}$. This reduction in $\mathrm{N}$ retention is presumably attributable to an increase in contribution of amino acids to gluconeogenesis. However, in steers nourished by intragastric infusion ${ }^{19)}, \mathrm{N}$ retention did not decrease until the propionic acid proportion reduced below $6 \mathrm{~mol} / 100 \mathrm{~mol}$, which is lower than that normally found in conventionally fed ruminants. This difference between our study and others ${ }^{19)}$ is probably due to the differences in glucose need between animals; our young calves probably required more glucose than the

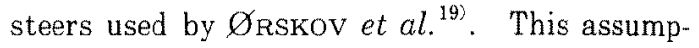
tion may be supported by the disagreement between our results and findings by $\varnothing$ RsKov et $a l .{ }^{19)}$ as described above: the response of the plasma concentration of glucose and $\beta$ HOB to low propionic infusion differed. Therefore, in young calves during a few weeks after weaning, high propionate supply probably has a important significance in sparing amino acids used for glucose production in the liver. In the case of feeding high concentrate diets to earlyweaned calves, the ruminal molar proportion of propionate reached above $40 \mathrm{~mol} / 100 \mathrm{~mol}^{32)}$. On the other hand, Sтово et al. ${ }^{29)}$ found that feeding high roughage diets to young calves reduced the propionate proportion to approximately $17 \mathrm{~mol} / 100 \mathrm{~mol}$. Under such conditions of the low propionate proportion, amino acids may be used preferentially as a glucogenic precursor rather than for body protein synthesis, even though calves require large quantities of amino acids for body protein synthesis.

Nitrogen retention of calves infused with the low propionate mixture reduced at 10 and 12 wh of age, but $N$ retention did not differ between treatments at $14 \mathrm{wk}$. This temporary reduction and subsequent elevation in $\mathrm{N}$ retention for calves infused with low propionate mixture may have occurred due to the change in utilization of glucose associated with advancing age ${ }^{8)}$ or nutritional adaptation ${ }^{15)}$. In rats ${ }^{15)}$, changing a high carbohydrate diet to a high fat diet induced a temporary reduction in $\mathrm{N}$ retention for a few days, but subsequently $\mathrm{N}$ retention returned to the initial levels. This change in $\mathrm{N}$ retention was related to alteration 
of amino acid dehydrogenase activity in the liver ${ }^{15)}$. In ruminants, the change in activity of gluconeogenic enzymes associated with dietary change ${ }^{26)}$ and ruminal development ${ }^{51}$ also have been reported.

In conclusion, the results of the present study indicate that, for a few weeks after weaning, the decrease in the ruminal propionate proportion probably reduces the $\mathrm{N}$ use for body protein synthesis in young calves, even though the decrease in the propionate proportion is within the normal range found in ruminants.

\section{Acknowledgments}

This study was supported by a Grant-in-Aid for Scientific Research (No. 63760231) from the Ministry of Education, Science and Culture, Japan.

\section{References}

1) Agricultural Research Council, The Nutrient Requirements of Ruminant Livestock. 121-181. Commonwealth Agricultural Bureaux. England. 1980.

2) Agricultural Research Council, The Nutrient Requirements of Ruminant Livestock. Supplement no. 1. 15-24. Commonwealth Agricultural Bureaux. England. 1984.

3) Armentano, L.E., Ruminant hepatic metabolism of volatile fatty acids, lactate and pyruvate. J. Nutr., 122 : 838-842. 1992.

4) Baldwin, R.L., VI, and B.W. Jesse, Developmental changes in glucose and butyrate metabolism by isolated sheep ruminal cells. J. Nutr., 122 : 1149-1153. 1992.

5) Bartley, J.C., R.A. Freedland and A.L. BLACK, Effect of aging and glucose loading on the activities of glucose-6-phosphatase and phosphorylase. Am. J. Vet. Res., 27 : 1243-1248. 1966.

6) Blaxter, K.L., Energy Metabolism in Animals and Man. 295-297. Cambridge University Press. Cambridge. 1989.

7) CERIOTTI, G., Ultramicrodetermination of plasma urea by reaction with diacetylmonoxime-antipyrine without deproteinization. Clin. Chem., 17 : 400-402. 1971.

8) Colvin, H.W., JR., J.T. AtTEBeRY and
L.B. Daniels, Effect of diet on glucose tolerance of dairy calves one to thirteen weeks old. J. Dairy Sci., 50 : 362-370. 1967.

9) Deyle, $Z$. and M. Horakova, Profiling of amino acids in fluids and tissues by means of liquid chromatography. $J$. Chromatogr., 379: 177-250. 1986.

10) Eskeland, B., W.H. Pfander and R.L. PRESTON, Intravenous energy infusion in lambs: effects on nitrogen retention, plasma free amino acids and plasma urea nitrogen. Br. J. Nutr., 31 : 201-211. 1974.

11) Harris, P.M. and G.E. Lobley, Amino acids and energy metabolism in peripheral tissues of ruminants. in Physiological Aspects of Digestion and Metabolism in Ruminants. (TSUDA, T., Y. SASAKI and R. Kawashima, eds.) 201-230. Academic Press. San Diego. 1991.

12) Kabasakalian, P., S. Kaldiney and A. Westcort, Enzymatic blood glucose determination by colorimetry of $\mathrm{N}, \mathrm{N}$-diethylaniline-4-aminoantipyrine. Clin. Chem., 20: 606-607. 1974.

13) Mackaz, J.C. and G.E. Lobley, Some factors which influence thermal energy losses during the metabolism of ruminants. Livest. Prod. Sci., 9: 447-456. 1982.

14) MCLean, J.A. and G. TOBIn, Animal and Human Calorimetry. 94-112. Cambridge University Press. Cambridge. 1987.

15) Nakano, $K$. and K. Ashida, Energy metabolism and amino acid metabolisms. Protein Nuclic acid Enzyme, 14: 1328-1335. 1969. (in Japanese)

16) Obitsu, T., K. Taniguchi and $Y$. Yamatani, Application of a method of intragastric nutrient infusion to young calves. Anim. Sci. Technol. (Jpn.) (in Press)

17) Ørskov, E.R., D.A. GrubB, G. Wenham and W. Corrigall, The sustenance of growing and fattening ruminants by intragastric infusion of volatile fatty acid and protein. Br. J. Nutr., 41: 553-559. 1979.

18) Ørskov, E.R., D.A. GrubB, J.S. SMith, A.J.F. Webster and W. Corrigall, Efficiency of utilization of volatile fatty acids for maintenance and energy retention by sheep. Br. J. Nutr., 41 : 541-551. 1979.

19) Ørskov, E.R., N.A. MAcLeod and Y. Nakashima, Effect of different volatile fatty acids mixtures on energy matabolism 


\section{Obitsu, Taniguchi and Yamatani}

in cattle. J. Anim. Sci., 69: 3389-3397. 1991.

20) OMorI, S., Development of digestive function and metabolic alterations in the young ruminant. Jpn. J. Zootech. Sci., 43 : 231-238. 1972. (in Japanese)

21) Quigley, J.D., III, L.A. Caldwell, G.D. Sinks and R.N. HeitmanN, Changes in blood glucose, nonesterified fatty acids, and ketones in response to weaning and feed intake in young calves. J. Dairy Sci., $74: 250-257.1991$.

22) Reid, J.T., O.D. White, R. Ainrique and A. Fortin, Nutritional energetics of livestock: some present boundaries of knowledge and future research needs. J. Anim. Sci., 51 : 1393-1415. 1980.

23) Reynolds, C.K., H.F. Tyrrell and P.J. REYNoLds, Effects of diet forage-to-concentrate ratio and intake on energy metabolism in growing beef heifers: net nutrient metabolism by visceral tissues. J. Nutr., 121 : 1004-1015. 1991.

24) Rook, J.A.F., Nutritional imbalances, in Nutritional Physiology of Farm Animals. (Rook, J.A.F. and P.C. Thomas, eds.) 369-379. Longman - London. 1983.

25) Sasaki, Y., K. Takeshita, S. Watanabe and T. AsAI, Development of the utilization of volatile fatty acids in young calves observed by arterio-venous difference. Jpn. J. Zootech. Sci., 40 : 139-150. 1969.

26) Scatfe, J.R. and N.S. Jessop, The influence of diet on the activity of certain lipogenic and glucogenic enzymes in sheep liver and adipose tissue. Biochem. Soci. Trans., 15 : 827-828. 1987.
27) SeKrne, J., T. MorookA, M. OKubo and Y. AsAHIDA, The estimation of metabolizable energy requirements for maintenance and growth of growing calves weaned at six weeks of age. Jpn. J. Zootech. Sci., 58: 266-272. 1987.

28) Sekine, J., R. Oura, S. Morma, T. MorookA, and Y. Asahida, Effect of age on energy utilization of early weaned growing calves weighing less than $100 \mathrm{~kg}$. Anim. Prod., 48: 75-79. 1989.

29) Stobo, I.J.F., J.H.B. RoY and H.J. Gaston, Rumen development in the calf. 2. The effect of diets containing different proportions of concentrates to hay on digestive efficiency. Br. J. Nutr., 20: 189215. 1966.

30) Trenkle. A.H., Amino acid metabolism and hormonal control during growth. in Digestive Physiology and Metabolism in Rumiants. (Ruckebush, Y. and P. Thivend, eds.) 505-522. MTP Press. England. 1979.

31) Tyrrell, H.F., P.J. Reynolds and P.W. MOE, Effects of diet on partial efficiency of acetate use for body tissue synthesis by mature cattle. J. Anim. Sci., 48: 598-606. 1979.

32) Williams, P.E.V., G.M. Innes, A. Brewer and J.P. MAGADI, The effect on growth, food intake and rumen volume of including untreated or ammonia-treated barley straw in a complete diet for weaning calves. Anim. Prod., 41 : 63-74. 1985.

33) Williamson, D.H., J. Mellanby and H.A. KREBS, Enzymic determination of $D(-)-\beta-$ hydroxybutyric acid and acetoacetic acid in blood. Biochem. J., 82 : 90-98. 1962. 
VFA Utilization in Early Weaned Calves

精製栄養素の胃内給与法により飼育した早期離乳子牛の

エネルギーと窒素利用に及ぼす

揮発性脂肪酸組成の影響

小櫝剛人・谷口幸三・山谷洋二

広島大学生物生産学部，東広島市 724

精製栄養素の罢内給与法を用いて，第一胃内注入揮発性脂肪酸（VFA）組成と週齢の違いが，早期 離乳子牛のエネルギーと窒素利用に及ぼす影響を捈討した。 ホルスタイン種雄子牛 6 頭を用い, 3 頭に は酶酸,プロピオン酸, 酪酸のモル比を $48: 42: 10$ とするVFA 混合液を, 残りの3頭には同 $76: 14$ : 10 とするVFA 泥合液を, 主要ミネラルおよび緩衝液とともに第一胃内人注入した。第四胃内へは力 ゼイン, 微量ミネラル, ビタミンを注入し, 離乳 (5から7週路) 後はこれらの注入精製栄養菜のみで

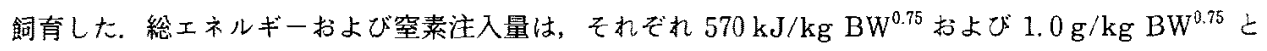
した，6から 14 週齢の問， 2 週問每に血液成分，発熱生量，窒素出納を測定した，血䍝中グルコース濃 度とßー七ドロキシ酪酸濃度にはVFA 組成の影響が認められた。熱発生量にはVFA 組成の影響は 琶められなかったが，週齢の進行にともない隇少する傾向がみられた。窒素蓄積量は，プロピオン酸制 合の低いVFA 液を注入した場合に，10から 12 週齢にかけて低い傾向にあった，以上の結果より，幼 龄子牛では, 反罚家畜において通常の飼育下でみられるVFA 組成の範囲内であっても, プロピオン 酸割合が低い場合には，離乳後一時的に窒䒺蓄積量が低下することが示惨された。

日畜会報, $64(6) ： 568-577,1993$ 